\title{
TÁRSADALOMTUDOMÁNY
}

\author{
Boda Mihály
}

\section{Háborús ideológiák a középkori \\ Magyarországon: istenítéleti ideológia, az igazságos háború elmélete ${ }^{1}$}

\author{
DOI 10.17047/HADTUD.2021.31.1.62
}

A háborús ideológiák a háború igazolását szolgálják ma, és szolgálták a keresztény középkorban is. Az alábbi tanulmány két középkori ideológiával foglalkozik: a Sevillai Izidor nevéhez kapcsolható istenítéleti ideológiával, ami Isten igazságos ítéletéhez kapcsolja a háború (utólagos) igazolását és Aquinói Szent Tamás igazságos háború elméletével, ami a legitim autoritással rendelkezõ fejedelemnek az igazságos okra (azaz az ellenség által elkövetett igazságtalanságra) alapozott és a keresztény békének a védelmét célzó döntéséhez kapcsolja a háború (elõzetes) igazolását. A két ideológiában közös, hogy egyaránt az igazságosság eszméjére támaszkodnak, azonban amíg az istenítéleti ideológia az eljárási igazságosságra, addig az igazságos háború elmélete a tartalmi igazságosságra. A tanulmány egyik célja, hogy a filozófiai jellegû elméletalkotás és a történelemtudomány módszereinek a segítségével bemutassa, hogy az igazságos háború elmélete a középkorban nemcsak az Aquinói Szent Tamás által képviselt változatot jelentette (bár csak azt nevezték így), hanem volt egy másik formája is, az istenítéleti ideológia. A tanulmány másik célja, hogy mindezt magyarországi példák segítségével tegye, bemutatva ezzel a háborús ideológiák két fontos típusának középkori magyarországi formáit. KULCSKIFEJEZÉSEK: istenítélet, igazságos háború elmélete, Temesvári Pelbárt

\section{Warfare ideologies in medieval Hungary: ideology of judgement of God, just war theory}

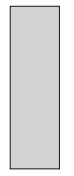

Warfare ideologies serve for justification of war today, and did in the Christian Middle Ages as well. This paper deals with two examples of medieval ideologies: the ideology of the judgement of God, connected to Isidore of Seville, which justifies wars posteriorly referring to the just judgement of God; and the just war theory of Saint Thomas Aquinas, which connects prior justification to the decision of the prince having legitimate authority and based on the

Nemzeti Közszolgálati Egyetem, Hadtudományi és Honvédtisztképzõ Kar - National University of Public Service, Faculty of Military Science and Officer Training; e-mail: boda.mihaly@uni-nke.hu; https://orcid.org/0000-0003-3037-3644 1_Ａ tanulmány a

Bolyai János Kutatási Ösztöndíj támogatásával készült. 
just cause (the enemy's unjust deeds) and right intention (defending the peace of the Christian community). The two ideologies have the concept of justice as a common point, however the ideology of the judgement of God relies on procedural justice, and just war theory builts on substantive justice. The first aim of this paper is to emphasizing just war theory in the middle ages did not contain the just war theory of Saint Thomas Aquinas only (however it was called only on that name), but it has another form as well, the ideology of judgement of God. The second aim is to attain this with the help of Hungarian examples, presenting two forms of the medieval Hungarian warfare ideologies. KEY EXPRESSIONS: judgement of God, just war theory, Pelbart Temesvari

\section{Bevezetés: középkori keresztény háborús ideológiák}

A középkori keresztény háborús ideológiák egytõl-egyig - tág értelemben vett - szentháborús ideológiák, azaz mutatnak valamilyen kapcsolatot Isten ítéleteivel, törvényeivel, szándékaival, parancsaival vagy a vallás védelmével és terjesztésével. Ezek az ideológiák négyes gyökérrel rendelkeznek, amelyek a zsidó nép történetéig (Ószövetség), a Római köztársaság korába (Cicero), a keresztény ókorba (Szent Ágoston), végül a kereszténygermán államalakulatok politikai gondolkodásáig (Sevillai Izidor) nyúlnak vissza. ${ }^{1}$ Ennek megfelelõen a nyugati középkori háborús ideológiák sokarcúak, ide tartozik az istenítéleti ideológia, az igazságos háború elmélete, a pacifizmus és a szûkebb értelemben vett szentháborús ideológia is. ${ }^{2}$

A 4. századig az ókeresztény pacifizmus volt a legfontosabb keresztény viszonyulás a háborúhoz, azaz a kereszténység számos, különbözõ indok miatt elvetette a háborút. Késõbb a pacifizmusnak ezt a formáját felváltotta a megváltás erõszakos, büntetésen keresztül való terjesztésének, a sajátosan középkori keresztény, Szent Ágoston nevéhez kapcsolódó háborús ideológiája. Szent Ágoston azonban csak nagy vonalakban, különbözõ munkáiban szétszórva dolgozta ki elképzeléseit. Ennek is köszönhetõen a korai középkor nagy részében az õ elképzelései helyett inkább Sevillai Izidor gondolatainak volt jelentõsége, ${ }^{4}$ aki az istenítéleti ideológia egyik elméleti megfogalmazója volt. Az érett középkorban aztán többek között a középkori (10-11. századi) pacifizmus sajátos, nem annyira békés eszméi által, illetve Szent Ágoston gondolatainak a felelevenítésével és szisztematizálásával megfogalmazták az egyház céljait szolgáló, és az egyház által kezdeményezett keresztes háborús ideológiát, illetve az egyház és a fejedelmek céljait is szolgáló, de a fejedelmek által kezdeményezett, igazságos okon alapuló igazságos háború elméletét.

A magyar állam alapítása után az Európában népszerû háborús igazolási formák megjelentek Magyarországon is. A továbbiakban az istenítéleti ideológia és az igazságos háború elméletének a magyar változatait mutatom be.

\section{Az istenitéleti ideológia}

Az istenítéleti ideológia legfontosabb jellemzõje az eljárási (procedurális) igazságosság: ${ }^{3}$ Isten természete és képességei által igazságos ítéleteket hoz, amiben nem támaszkodik olyan

\footnotetext{
${ }^{1}$ Vö. Wallace, Hadrill 1975, 157-159.

${ }^{2}$ Áttekintésként lásd: Tessore 2003, 23-76. Erdõ 2017, 269-281. 4

Canning 2002, 70.

${ }^{3}$ Barry1967, 97.
} 
értelemben tényekre, hogy azokat más, például az emberek képesek lennének elõre megismerni. Isten ítéletei nem lehetnek igazságtalanok, akármit is ítél, az igazságos lesz. Az igazságos és kegyes élet vitelével (például az emberölés kerülésével, illetve megtörténte esetén bûnbánat gyakorlásával) befolyásolni lehet az isteni ítéletet, azonban azzal sem lehet biztosra menni. Az igazságos és kegyes életnek ugyanis az élet minden pillanatát magában kell foglalnia, sõt a felmenõk tetteit és azoknak a leszármazottakra vonatkozó következményeit is. Ennek egyik következménye, hogy csak a háború megindítása, megvívása és a gyõzelem megszerzése (vagy a vereség elszenvedése), azaz az istenítélet megismerése után lehet biztosat mondani arról, hogy vajon igazságos volt-e a háború vagy sem az adott oldal számára, és így csak utólag lehet igazolni a háborúkat. Az istenítéletre jellemzõ igazságosság egy másik velejárója, hogy ugyan egy nagyon speciális értelemben, de szükségképpen pártos. Az ítéletet hozó Isten mindenképpen kedvezni fog a (választott) népét vezetõ (választott) királynak, ha úgy ítéli, hogy a nép tagjai és különösen a király igazságos és kegyes életet él a háború elõtt, alatt és utána. A választott nép ellensége ekkor, bármit is tesz, csak az igazságtalan oldalra kerülhet, és csak vesztes lehet a háborúban. Isten azonban nem teljesen pártos, hanem úgy fogalmazhatunk, hogy „objektíven pártos”, mivel amennyiben a választott nép vagy királya (akinek példát kell mutatni népe számára) istentelen életet él(t), akkor bármit is tegyen az ellenség, legyen akár pogány is, Isten általa meg fogja büntetni a választott népet és királyt. ${ }^{4}$ Nézzünk néhány példát az istenítéleti ideológiára a magyar középkorból!

A korai középkor fontos eseményei közé tartozik a magyar állam megalapítása és megerõsödése a 11-12. században. A magyar állam helyét és szerepét a kereszténységen belül I. (Szent) István király az Intelmek címû királytükörben jelölte ki. ${ }^{7}$ Az Intelmek szerint, ami alapján a magyar királyság teokratikus monarchia, a vallásos-szent elem és az isteni törvények mellett a királynak a világi-politikai hasznossági elképzeléseknek és a világi szokásoknak is szerepet kell szánnia a kormányzásban. A király az univerzális keresztény birodalom (István koronázásakor III. Ottó birodalma) egy szeletén Isten kegyelmébõl uralkodik, és az ezzel összefüggõ feladata, hogy védelmezze alattvalóit, azaz gondoskodjon róluk, legyen igazságos és irgalmas az ország minden lakosával; illetve hogy gyarapítsa az egyházat, azaz folytasson térítést. Erre akkor van lehetõsége, ha megtartja a keresztény hitet, és abban képes mások példaképévé válni. Ugyanakkor, az uralkodás célja nem csupán a keresztény méltóság fenntartása és gyarapítása, hanem az emberi hasznosság elõsegítése is, amiben pedig nem csupán az isteni törvényeket ismerõ fõpapok adhatnak tanácsot (Isten törvényeit közvetítve), hanem a királyi tanács is (a világi szokásokat közvetítve). A királynak ezeken a tanácsokon túl, egy általánosabb megközelítésben, az izraeli vezetõk és királyok (például Józsué, Dávid, Salamon) és a ,római” királyok (I. [Nagy] Konstantin, ${ }^{5}$ III. Ottó ${ }^{6}$ ) példáját is követnie kell. Amennyiben a király nem követné az isteni törvényeket, a világi szokásokat, a régi királyok példáját, illetve magukat az Intelmekben adott tanácsokat, akkor Isten megbünteti, büntetéseként pedig a fõemberek és a katonái ellene fordulnak, és a királyság másra száll át.

\footnotetext{
${ }^{4}$ Isidore of Seville 2006, 117-118., 199-200., 359-360.; Isidore of Seville 2018. 7

Szent István 2014, 13-33.; Szûcs 1988, 32-53.

5 Szûcs 1988, 34-35.

${ }^{6}$ Balogh 1927, 89-95.
} 
Az isteni büntetés elkerülése és a gyõzelmek elérése végett a király számára a hit megtartása, a rendszeres imádkozás, a bûnöktõl való megtisztulás és az áhítatos lelkület megszerzése kiemelten fontos. Így fogalmaz az Intelmek: „Akik ugyanis hamis hiten vannak vagy a hitüket nem teszik teljessé és nem ékesitik fel cselekedetekkel, minthogy a hit cselekedet nélkül halott, sem itt nem uralkodnak dicsõséggel, sem az országnak és koronának nem lesznek részei. Ha viszont a hit pajzsát megõrzöd, birtokában leszel az örök élet sisakjának is. A lélek eme fegyvereivel azután törvényesen küzdhetsz majd a látható és láthatatlan ellenségeid ellen egyaránt. Az apostol ugyanis ezt mondja: aki bajvívásban tusakodik is, meg nem koronáztatik, ha nem a törvény szerint tusakodik. "7

A szövegben ugyan nem szerepel expressis verbis, hogy a hittel élõ király Isten ítéletével fog gyõzni ellenségeivel szemben, azonban a hittel való élet és a gyõzelem összefüggése nyilvánvaló, és a biblikus idézet miatt talán feltételezhetjük Isten szerepét is ebben az összefüggésben. Így az Intelmek tartalmaz példát az istenítéletnek mind a büntetõ, mind pedig a gyõzelemre vezetõ formájára.

I. (Szent) István király tetteirõl a 11. század második felében írva, a Képes Krónika és a király mindhárom legendája kiemeli a Koppánnyal folytatott harc leírásánál az István által élt kegyes életet, illetve az isteni segítséget. A Nagy legenda szerint a világon minden történést Isten irányít, még a pogány népek viselkedését is. Így lehetett a még pogány magyar nép az a nép, amit Isten a „,napnyugati” keresztények eltévelyedéseinek a megbosszulására rendelt. ${ }^{8}$ Isten a kereszténység felvételét követõen tovább vezette a magyar népet, most már a kegyes életet élõ István király által, amikor István megtámadta a Veszprém közelében tábort verõ Koppányt és seregét. A Nagy legenda nem gyõzi halmozni István kegyességének a jelzõit. István a pogányokat ,a dicsõséges kereszt jelének pártfogásával, Isten szülõanyja, az Örök Szûz Szent Mária érdemeinek oltalmával Isten kedveltje, Márton fõpap és Szent György vértanú zászlaja alatt, vezéreik megölése után csakhamar szolgálatába hajtotta, a keresztség vizében megfürösztötte..."9

A Kis legenda pedig nemcsak arra hívja fel a figyelmet, hogy István hithû életet élt, hanem arra is, hogy hithû keresztény királyként kormányzott: „Az isteni kegyelemtõl vezérelt király rajtuk ütött; ezek hitükben, azok bizony csak a fegyverekben bizakodtak, s mindkét részrõl küzdöttek. Végül az ellenséget legyõzték... . Ezenfelül birtokaikról-mind a földekrõl, mind a falvakról - bölcsen rendelkezett... . Mert mindenekbõl semmit nem tartott meg a maga szükségére, hanem elmenvén, Szent Mártonnak szentelte, akinek tiszteletére bazilikát épített. Õket pedig és utódaikat mind a mai napig az egyház szolgáivá tette."10

István igazságos és kegyes életvezetésének a következményére további példákat találhatunk a legendákban. Az egyik szerint II. Konrád támadásáról hírt szerezve, István könyörgött Szûz Máriához, hogy amennyiben õ (István) bûnös lenne, akkor õt és a népét büntesse, majd ezt követõen István csellel visszaverte Konrád seregét, ami után hálát adott Krisztusnak és Szûz Máriának. Egy másik példa pedig összefüggésbe hozza Istvánnak az elesetteken való segítõ viselkedését azzal, hogy azt követõen Isten figyelmeztette Istvánt

\footnotetext{
${ }^{7}$ Szent István 2014, 1. 21-22.

${ }^{8}$ Szent István király nagy legendája. In Árpád-kori legendák és intelmek. 1983, 23-24.

${ }^{9}$ Uo. 26.

${ }^{10}$ Szent István király kis legendája. uo. 18.
} 
álmában a besenyõk betörésére, és így István fel tudott készülni a harcra. Egy harmadik példa pedig az istváni törvények István általi igazságos alkalmazása a békésen betelepülõ besenyõket megtámadó határõrökkel szemben. ${ }^{11}$

Az istváni példát követte I. (Szent) László király is, aki kezdeményezte István szentté avatását (1083). ${ }^{12}$ László tetteirõl a Képes Krónikából és Szent László király legendájából értesülhetünk. Szent László és testvére, I. Géza király sorsát Isten - a krónikaíró szerint - a kezdetektõl fogva szem elõtt tartotta és irányította. Salamon királynak (és testvérének) ugyanis Isten büntetésének köszönhetõen nem lett utódja, így halálával az Árpád-ház egy másik ága, a Lászlót is magába foglaló Béla-ág került trónutódlási helyzetbe.

I. (Szent) László 12. század végén készült legendája szerint Szent Lászlót, testi és lelki erényei miatt, az Úr földi helytartójául állította, ${ }^{13}$ aki azonban királyként sem a méltóságot kívánta, hanem azt, hogy gondoskodhasson az embereken. ${ }^{14}$ Legfontosabb erényei az istváni erények, a kegyesség és az igazságosság voltak. ${ }^{15}$

Életének fontos epizódja, hogy még hercegként testvérével, Géza herceggel, a mogyoródi csatában (1074) legyõzte a Salamont. A Krónika így kommentálja az eseményeket: „Géza és László herceg pedig, miután az isteni akarat a gyõzelem diadalmával fölmagasztalta õket, a megöltek holttestei fölött háromszor mondtak fönnhangon dicséretet az Istennek. László herceg, minthogy mindig rendkivül kegyes szívû volt, látva a sok ezer meggyilkoltat ámbár ellenségei voltak, akiket megöltek-, mégis 'egész bensõjében megrendült' miattuk, és siratta õket keservesen, nagy jajveszékeléssel, arcát marcangolva és haját tépve, akár az anya fiainak temetésekor. Késõbb az ezektõl szerzett zsákmányból épült a mogyoródi egyház."16

László igazságosságára és kegyességére további példákat is találhatunk a Krónikában: amikor László Moson várát ostromolta, ahová Salamon menekült, akkor a kiéheztetett várvédõk kijöttek Lászlóhoz, aki „,kegyes bõkezûséggel bánt velük és megengedte, hogy szabadon visszatérjenek urukhoz"; ${ }^{17}$ vagy amikor a cserhalmi csata (1068) után egész Magyarországon ,'himnuszokkal és imádságokkal áldották az Istent', aki gyõzelemmel ajándékozta meg õket". ${ }^{18}$

Összeségében azt mondhatjuk, hogy az uralkodói példák bizonyítják annak a világképnek a meglétét a 11-12. századi Magyarországon, amiben helye van az istenítéleti ideológiának. A példákban egyaránt találunk utalást a háború elõtti (István az elesetteken segít), háború alatti (István Szûz Máriához könyörög, László megsiratja az ellenség elesett harcosait) és a háborút követõ (hálaadás az Úrnak, Krisztusnak vagy Szûz Máriának, himnuszok éneklése) kegyes életvitelre. A példákon túl azonban a Krónika Lászlónak tulajdonít egy olyan, a háború természetére vonatkozó állítást (elméletkezdeményt) is, ami

\footnotetext{
${ }^{11}$ Szent István király nagy legendája. uo. 30-31.; Szent István király kis legendája. uo. 20.

${ }^{12}$ Vö. Ujházi, Horváth 2020, 193-210.

${ }^{13}$ Szent László király legendája. In Árpád-kori legendák és intelmek. 1983, 95.

${ }^{14}$ Uo. 97.

${ }^{15}$ Uo. 97.

${ }^{16}$ Képes Krónika. 2004, (122.) 80.

${ }^{17}$ Uo. 162.

${ }^{18}$ Uo. 134. Máskor hálált adnak az Úrnak a kunok feletti gyõzelemért: uo. 172.
} 
összefüggésben van az istenítéleti ideológiával. A kemeji csatát (1074) követõen, ahol Salamon árulás segítségével legyõzte Gézát, és akivel ezt követõen László Vácnál találkozott, László így reagált arra, hogy Géza sírva fakadt, mert elveszítette a katonáit: „inkább a mindenható Isten kegyelméért könyörögjön, hogy a gyõztest vesse alá a legyõzötteknek, ahogyan az sokszor megesik a háborúkban” ${ }^{19}$ (más fordításban: „kérje inkább a mindenható Isten kegyelmét, hogy vesse a gyõztest a legyõzöttek hatalma alá, ahogyan ez a háború rendje" ${ }^{20}$ ). Az állításban a (kegyes) királynak az Istennel való viszonya fontos összefüggésben van a király gyõzelmével.

\section{Az igazságos háborús gondolkodás hagyománya Magyarországon: a Képes Krónika, Anonymus és Temesvári Pelbárt}

Az igazságos háborús gondolkodás hagyományának elsõ szisztematikus-elméleti megfogalmazása Aquinói Szent Tamás (1225-1274) nevéhez kapcsolódik. Az elmélet szerint ahhoz, hogy valamely háború igazságos legyen, három dolog szükséges: legitim autoritás, azaz a fejdelem felhatalmazása, akinek a parancsára háborúba szállnak; igazságos ok, azaz hogy az ellenség valamilyen korábban elkövetett igazságtalan, jogsértõ tettével rászolgáljon a támadásra és a helyes szándék, azaz hogy a támadók a keresztény béke állapotának elérésére törekedjenek. ${ }^{21}$ A Szent Tamás-i elmélet összeségében a háborút abban az eseteben igazolja, ha a fejedelem a korábban igazságtalanságot, jogsértést elkövetõket megbüntetve fenntartja és védi a keresztény közösség békéjét.

Magyarországon az igazságos háborús gondolkodás hagyománya elméleti formában csak viszonylag késõn, Temesvári Pelbártnál (1435-1504) jelent meg. Elõtte is beszélhetünk azonban talán az igazságos vagy pontosabban, az igazságtalan magánerõszak-használat (hatalmaskodás) oklevelekben tükrözõdõ gyakorlatáról, ${ }^{25}$ illetve az igazságos háborúról való gondolkodás egy olyan hagyományáról, amit a krónikaés gesztaírók közvetítettek.

Az igazságos háborús gondolkodás hagyománya a magyar történetírói hagyományban

A Képes krónika (a 14. században került összeállításra, de a részei a 11. századtól kezdve keletkeztek) és Anonymus A magyarok cselekedetei (1200 körül) címû munkája egyaránt tartalmazza a magyar honfoglalás leírását, aminek központi eleme a fehérló-monda.

A honfoglalás három részét különböztethetjük meg, a bolgárok uralta Erdély birtokba vételét, a morvák (Szvatopluk / Salán) uralta Alföld elfoglalását, és a frankok uralta Dunántúl birtokba vételét. Ezen fázisok közül a fehérló-monda a morva területek elfoglalásához kapcsolódik.

A monda szerint - amelyet összetettsége és értelmezési nehézségei miatt érdemesnek tartok hosszabban is idézni - miután a magyarok felderítették a morvák földjét, követet küldve felvették a kapcsolatot a morvák fejedelmével (Szvatoplukkal / Salánnal), akinek a

\footnotetext{
${ }^{19}$ Képes Krónika. 2004, (117.) 77.

${ }^{20}$ Képes Krónika. 1986, [117.] 146.

${ }^{21}$ Vö. Aquinói Szent Tamás. 2014, 40. kérdés (1) 265. Az igazságos háború elméletének középkori megjelenésérõl, fejlõdésérõl Szent Ágostontól kezdve, és képviselõirõl lásd: Russell 1975. 25 Tringli 2017, 12-16.
} 
hazatérése után megtanácskozták a kérdést, hogy miként is foglalják el a területet. Ez után a Képes Krónika szerint: „a követet közös elhatározással visszaküldték az imént említett fejedelemhez, és földje fejében egy nagy lovat küldtek neki, Arábia aranyával aranyozott nyereggel és aranyozott kötõfékkel. A fejedelem ennek láttán még inkább örvendezett, mert azt gondolta, hogy a földjéért valamiféle vendégajándékot küldtek neki. A követ pedig ekkor a fejedelemtõl földet, füvet és vizet kért. A fejedelem mosolyogva így szólt: 'Vegyenek csak, amennyit akarnak, ezért az ajándékért!' 'gy azután a követ visszatért övéihez.

Közben Árpád és a hét vezér bevonultak Pannóniába, de nem mint jövevények, hanem mint örökség jogán a föld birtokosai.

Ekkor egy másik követet küldtek a fejedelemhez, és ezt az üzenetet bizták rá: 'Árpád az övéivel egyetemben ezt mondja neked: azon a földön, amelyet megvásároltak tõled, tovább semmiképpen se maradj; mert földedet megvették a lovon, füvedet a kötõféken, vizedet a nyergen. S te örökbér ellenében, azaz ínségedben és mohóságodban átengedted a földet, a füvet és a vizet.' ... '... Ha tehát a föld, a fû és a viz az övék, minden az övék. ",22

A mondát Anonymusnál is megtaláljuk, és bár ez a változat némileg eltér a Krónikától, azonban a számunkra fontos kérdésekben, azaz a morvák elleni háború igazolásának a kérdésében, nagyrészt megegyezik azzal. Két eltérés, hogy Anonymusnál hangsúlyosabb az az elem, hogy a Duna-Tisza köze Attila, hun király örökségeként is megilleti Árpádot és a magyarokat, és nála az ajándékok száma megemelkedik. ${ }^{23}$

A mondának többféle értelmezése van, ${ }^{24}$ amelyek közül némelyek radikálisan eltérnek egymástól. Györffy György szerint a monda egy korábban megkötött magyar-morva szövetség emléke, ${ }^{25}$ Engel Pál szerint pedig éppen ellenkezõleg, a megkötött magyar-morva szövetség egyoldalú - magyar - felmondásának és a morva területek elfoglalásának a szépítését, a szövetségszegés pszichológiai feldolgozását foglalja magába. ${ }^{30}$ Ezen értelmezések szerint a monda tartalmának nincs direkt módon köze a honfoglaláshoz. Dallos Edina elképzelése szerint azonban a monda direkt módon a honfoglalás egyes eseményeit dolgozza fel. Ez utóbbi értelmezés alapján elemzem a mondát én is.

Dallos véleménye szerint a mondában több értelmezési réteg mosódott össze az idõk során. Megkülönböztethetünk egy eredeti, nomád réteget, egy lejegyzéskori, népi réteget és egy leírt réteget, amelyek kialakulása visszavezethetõ rendre egy

11. században még elõ nomád kulturális koncepcióra, az ezt felváltó keresztény kulturális koncepcióra és egy politikai koncepcióra. A nomád réteg része, hogy Árpád egyoldalúan országszimbólumokat (föld, fû, víz) kér a morva fejedelemtõl, amit az elküld neki. A keresztény népi réteg része, hogy a szimbólumok megküldését és a fehér ló (illetve Anonymusnál a többi ajándék) kicserélése valójában kétoldali, jogés kötelesség-keletkeztetõ vásárlási aktus. Végül, a politikai réteg fontos része, hogy a kérdéses országterület Árpád õséé, Attiláé volt.

\footnotetext{
${ }^{22}$ Képes Krónika. 2004, (28.) 28.

${ }^{23}$ Anonymus 1999, (14.) 20.

${ }^{24}$ Lásd bõvebben: Veszprémy 2019, 201-207.

${ }^{25}$ Györffy 1977, 128-129; Györffy 1993, 213-214. 30 Engel 2003, 659.
} 
A három értelmezési réteg háromféleképpen igazolja az országterület megszerzéséért kirobbant háborút a magyar oldalról. A nomád réteg szerint Árpád, a magyarok tiszteletet parancsoló hírnevét felhasználva, egyoldalúan behódolásra szólította fel a morvák fejedelmét (kérte az országszimbólumokat), aki be is hódolt neki (ahogyan a honfoglalást megelõzõen Halics vezetõje is ajándékokkal halmozta el Álmos vezért, és „,mintegy a saját uraként látta vendégül"26), azonban késõbb ki akart hátrálni az alárendelt viszonyból, amit azonban Árpád a háborúval megakadályozott. Ebben az esetben csak akkor lehet a háború igazolásáról beszélni, ha sikerül megtartani az uralmat, mivel az alárendelõdés kizárólag a hírnévnek (dicsõségnek, becsületnek) köszönhetõ. A hírnévbõl azonban nem keletkezik a hatalmi viszonyoktól független és az igazságosságot biztosító jog, hanem csak addig tart, amíg a hírnév fennáll (azaz, amíg le nem gyõzik a magyarokat). Így ezen réteg szerint, végeredményben, Árpád háborús lépése igazolt volt, azonban a becsület és nem az igazságosság alapján.

A keresztény népi réteg szerint Árpád kétoldali ügylettel vásárolta meg a földterületet, így az az õ tulajdonába került, jogot szerzett rá, ami a másik oldalon kötelességet eredményezett. Árpád a kötelesség megszegése és ezzel a jog megsértése alapján, azaz az igazságosság alapján igazoltan indíthatott háborút a terület birtokba vételéért.

Végül, a politikai változat szerint a terület elfoglalásáért indított háború azért volt igazolt, mert a terület valójában minden egyéb (egyoldalú vagy kétoldalú) ügylettõl függetlenül Árpádé volt, hiszen korábban Attila és a hunok területe volt, és így Árpád, Attila leszármazottja lévén, jogot szerzett a területre, ami a morva oldalon kötelességet eredményezett. Árpád a kötelesség megszegése és ezzel a jog megsértése alapján, azaz ismét csak az igazságosság alapján, igazoltan indíthatott háborút a terület birtokba vételéért. ${ }^{32}$

A monda két utóbbi értelmezési rétegének a témánk szempontjából való lényeges következménye az, hogy a monda lejegyzése és politikai felhasználása körüli idõszakban (1200 körül és talán korábban is) a magyar keresztény népi és politikai gondolkodásnak része volt az az igény, hogy a háborúkat igazolni kell, illetve ezzel együtt, hogy a háborúkat nem kezdeményezheti akárki. A monda különbözõ értelmezési rétegei ugyanis abban különböznek egymástól, hogy milyen (igazoló vagy igazságos) okot jelölnek meg a morvák ellen megindított háborúhoz: a hírnéven alapuló alávetettség fenntartását, a vásárlásból keletkezõ jog érvényesítését vagy az öröklésbõl keletkezõ jog érvényesítését. Az utóbbi jogérvényesítés esetén érdemes arra is felfigyelni, hogy határozottan kijelölõdik azoknak a személyeknek a köre, akik felhatalmazással rendelkeznek a háború megindítására, azaz akik rendelkeznek az igazságos háború megindításához szükséges legitim autoritással. Ezen személyek körébe az Árpád-házi királyok tartoznak bele.

Az igazságos háború elméletének ezek a kategóriái, amelyek a korszakban Európában sem voltak még teljesen tisztázottak, még a magyar népi kulturális és politikai gondolkodásban sem tudatosultak teljesen. Az európai és a magyar történeti hagyományban megjelenõ igazságos háborús gondolkodás hasonlósága azonban nem szembeötlõ: a háborúhoz szükség van igazságos okra, ami valamilyen jogsértéshez kapcsolódik, és aminek okán a legitim autoritással rendelkezõ személy, a fejdelem indíthat háborút. Ezen

\footnotetext{
${ }^{26}$ Anonymus 1999, (11). 17. 32

Dallos 2000, 140-141.
} 
hasonlóságok mellett azonban a különbség is szembeötlõ: a korszak európai igazságos háborús gondolkodása az igazságos háborúkat vallási bûn vagy világi igazságtalan tett (jogsértés) megbüntetéseként fogta fel, és nem jogérvényesítésként. A fehérló-mondában pedig jogsértésrõl van szó, de nem szerepel a háborúnak az az értelmezése, hogy Árpád megbüntette volna a morvákat a jogsértésért, hanem Árpád pusztán érvényesíti egy területre való jogát.

\section{Temesvári Pelbárt és az igazságos háború elmélete}

Temesvári Pelbárt (1435-1504) a György vitézrõl írt (harmadik) példabeszédében foglalkozik az igazságos háború elméletével, illetve említésszerûen a Szent László királyról szóló harmadik beszédében. ${ }^{2728}$

Temesvári egy Pál apostoltól vett idézetre alapozza beszédét: „Ezt a parancsolatot kötöm a lelkedre... hogy a jó harcot vívd meg... Tarts ki a hitben, és õrizd meg tisztán a lelkiismeretedet." ${ }^{34} \mathrm{Az}$ idézetet három részre lehet felosztani, amelyek alapján elemezni lehet a katonai kötelességeket. A három rész a „vívd meg a jó harcot”, ,ezt a parancsolatot” és a „tarts ki hitben és õrizd meg tisztán a lelkiismeretedet”, amelyekhez Temesvári egy-egy, a késõbbeikben tárgyalandó problémát rendel: a katonáskodás feltételeinek a problémáját, a katonai elõírások megõrzésének a problémáját és a hit jelentõségének a problémáját.

A katonáskodás feltételeit a katonai hivatás fogalmával lehet körülírni, ami négy feltételt foglal magába. A katona számára fontos a kellõ gyakorlás a fegyverforgatás terén és a fizikai állóképesség terén: ,a katona szó a gyakorlatozás és a fáradalom neve." 29 A gyakorlatozást azonban csak olyan módon szabad folytatni, amelyben nem fenyegeti közvetlen halálveszély a gyakorló feleket. Ilyen ,a lovakon való rohanások és fordulatok, az ütés és a védekezés mestersége, a dárdavetés". Határozottan nem ebbe a csoportba tartozik azonban a bajvívás, amely közvetlen halálveszéllyel fenyeget, és ezért tilos. A bajvívás „erõfitogtatásra való játék... . Nem dicséretes az igazságosság nélküli bátorság", 36

A harci jártasság fizikai képessége mellett fontos, hogy a katona helyes harci szándékkal is rendelkezzen. A helyes harci szándék nem állhat az ártani vágyásban, a kegyetlen bosszúállásban, a gyûlölködésben, az engesztelhetetlenségben vagy vad visszavágásban és az uralomvágyban. Arról, hogy mi is lenne a helyes szándék tartalma Temesvári ezen a ponton nem ad felvilágosítást, csak a beszéd egy késõbbi részén, azt azonban leszögezi, hogy ugyan másodjára tárgyalja a helyes szándékot, a fizikai képesség tárgyalása után, azonban a helyes szándék léte vagy nem léte határozza meg a fizikai képesség mûködését is. Ez azt jelenti, hogy hiába képzett valaki a fizikai képességek területén, amennyiben ezek a képességek nem a megfelelõ szándékkal párosulnak, akkor az illetõ nem bírhatja a keresztény katonai hivatást. $^{30}$

\footnotetext{
27 Temesvári 1982, 218-225.; Temesvári 2008, 225-237.

${ }^{28}$ Tim 1.18-1.19.; Temesvári 1982, 218.

${ }^{29}$ Temesvári 1982, 219. 36

Uo.

${ }^{30}$ Uo.
} 
A helyes szándékkal bizonyos értelemben együtt jár az, hogy a katonának ki kell tartania a helyes szándéka mellett, „,derekasan kell ellenállnia az ördögnek”. Amennyiben erre nem képes, akkor hiába helyes a szándéka, nem alkalmas katonának, hanem inkább papnak. A helyes szándék tartóssága adja ugyanis azt a kitartó bátorságot a harcban, ami által a katona képes szembeszállni az erõs ellenséggel is. ${ }^{31}$

A bátorság másik fontos feltétele a kitartás mellett az igazságosság. A királyok, mint a legfõbb katonák kötelessége, hogy „magukévá tegyék az ítélkezést és az igazságszolgáltatást", a többi katona kötelessége pedig engedelmeskedni a király ítéletein keresztül az igazságosságnak. Amennyiben a harcos nem engedelmeskedik a királynak, akkor nem katona, hanem rabló csupán. A háborúban így a király rendelkezik a legitim autoritással, azzal a felhatalmazással, hogy háborút indítson. A király csak közszereplõként ítélkezhet, és csak akkor, ha biztos, hogy az, aki felett ítélkezni kell, nem javul meg magától, mivel ekkor „a gonoszt a jogos ítélet megjavítja”. A magánszemélyek nem ítélkezhetnek semmilyen esetben, és a magán jellegû bosszúállást Isten számára kell fenntartani. ${ }^{32}$

Az igazságosság nem más, mint „,megadni kinek-kinek a magáét. Bernát szerint Istennek a szeretetet, tiszteletet és engedelmességet; a felebarátainknak pedig a testvéri szeretetet". ${ }^{33}$ Ezzel függ össze a Temesvári által tárgyalt második problémakör, a katonai elõírások megõrzésének a kötelessége, ami azokat a parancsokat foglalja magába, amelyeket a katonának szabályszerûen és általánosságban be kell tartania. Az elsõ (és a harmadik) ilyen parancs a háborúk igazságos céljait határozza meg, illetve ezzel összefüggésben a helyes szándék tartalmát is. Az igazságos háború célja nem lehet valami világi cél, hanem csakis Istenért lehet katonáskodni. Az Istenért való harc, egy kicsit konkrétabban fogalmazva, irányulhat a szent egyház védelmezésére és békéjének fenntartására, illetve a felebarát megsegítésére, a felebarátokból álló közösség védelmére és az Isten iránti tisztelet fenntartására. ${ }^{41}$

A háborúnak ezek az okai elsõ pillantásra védelmi jellegû háborút tesznek lehetõvé, ha az Isten iránti tisztelet fenntartását az eretnekek elleni harcként értelmezzük. Temesvári azonban utal arra, hogy az elnyomottakat is meg lehet védeni, és hogy a kiközösítetteket és a hitetleneket is meg lehet támadni, amely utóbbi esetben ismét csak értelmezhetõ az Isten iránti tisztelet fenntartásának a kötelessége. ${ }^{34}$ Ezzel a kiegészítéssel Temesvári háborús okai támadó (szent és nem csupán igazságos) háborúkat is igazolnak.

A második parancsolat értelmében a keresztény katonának a jelzett célok érdekében vállalnia kell a megsebesülés és a halál veszélyét is, amiért cserébe „kiérdemlik a menyországot, és üdvözülnek". Ez azonban csak egy feltétellel teljesülhet - és ez a negyedik parancsolat, akkor, ha a katona a csata elõtt megvallja bûneit és bûnbánatot tart. Csak ebben

\footnotetext{
${ }^{31}$ Uo. 220-221.

32 Temesvári 2008, 231-233.

33 Temesvári 1982, 221. Az idézetben említett „Bernát” Clairvaux-i Szent Bernát, akinek az „A Templom lovagjainak ajánlott könyv az új lovagság dicséretérõl” c. munkája (Veszprémy 1999, 167-205.) jelentõs hatással volt a háborúk igazolhatóságának keresztény megítélésére a középkorban (bár alapvetõen szûkebb értelemben vett szentháborús ideológiát jelenít meg). 41 Uo. 221-222.; Temesvári 2008, 227.

${ }^{34}$ Temesvári 1982, 220., 222., 223.
} 
az esetben biztosított ugyanis, hogy a katona helyes szándékkal menjen a csatába, ami pedig eredményezi azt, hogy kiérdemli a mennyországot és üdvözül. ${ }^{35}$

A páli idézetbõl fakadó harmadik kötelesség, a hithû katonáskodás kötelessége is ezzel függ össze, ugyanis a korábban vétkezõ katonától Isten megtagadja a gyõzelmet. Ezért minden katonának meg kell tisztulnia a bûnöktõl, és ,szilárdnak kell lennie a hitben, és lelkiismeretben tisztának a bûntõl'. A legrosszabb bûnök a gõgösség, a testi vétkek, a rablás és zsákmányolás, illetve a babonaság. ${ }^{36}$

Temesvári Pelbárt igazságos háborút illetõ elképzelésérõl az mondható, hogy az nem tiszta megfogalmazása az igazságos háború elméletének, hanem több szempontból is átmenetet képez a szentháborús és keresztes háborús elméletekkel. Temesvári talán leghangsúlyosabban írja elõ a felebarátoknak és az õket magába foglaló keresztény közösségnek, illetve ezen közösség békéjének a megvédését, azáltal hogy a király megbünteti a bûnöst. Ez az elképzelés Szent Tamás elképzelésének összefoglalása. Temesvári azonban megengedi a kiátkozottak és hitetlenek elleni harcot is, mégpedig két okkal: vagy a felebarátok elnyomásának a megszüntetése okán, vagy az Isten iránti tisztelet fenntartása okán. Amíg az utóbbi egyértelmûen a keresztény vallás terjesztését célozza, így szentháborús ideológia, addig az elõbbi az igazságos háborús és a szentháborús ideológiák elegye. Úgy vélem, hogy Temesvárinál mindhárom típusú háborús ideológia megtalálható, azonban a többivel össze nem vethetõ módon hangsúlyosabb a Szent Tamás-i igazságos háború elméletének a jelenléte.

\section{Összegzés}

Az igazságos háború elméletének hagyományos felfogása - mely a középkorban Aquinói Szent Tamáshoz, manapság pedig Michael Walzerhez kapcsolható - szerint egyes háborúk azért lehetnek igazságosak, mert valamilyen igazságtalanság elõzi meg, és ezáltal igazolja õket. A háború igazolásának két, fentebb bemutatott középkori példája egyaránt az igazságosság fogalmát állítja a középpontba, amíg azonban az anonymusi és Temesvári Pelbárt-i elmélet a háború elõtt elkövetett igazságtalan tettekbõl, azaz tényekbõl vezeti le a háború igazságosságát, addig a többek között az István- és László-legendákban megjelenõ istenítéleti ideológia Isten speciális képességei alkalmazásának - a háborút lezáró, ahhoz képest utólagos - eredményébõl (gyõzelem vagy vereség a háborúban). A két elmélet közül csak az elsõt szokás az igazságos háború elméletének hagyományos fogalma alá sorolni, holott a második elképzelésnek, az istenítéleti ideológia, is központi eleme az igazságosságra való hivatkozás. Ez alapján, úgy vélem, lehetséges kitágítani az igazságos háború elméletének a hagyományos fogalmát, és abban helyet találni az istenítéleten alapuló ideológiának is.

A bemutatott ideológiákat Nyugat-Európában elméleti igénnyel megírt munkák (többek között Sevillai Izidor és Aquinói Szent Tamás munkái) közvetítették a kortársaknak és az utókor számára, amelyek célja az ideológiák világos bemutatása volt. Az ideológiák Magyarországon is megjelentek, azonban itt azokat a hagiografikus, krónika-, geszta- és prédikációirodalom õrizte meg, nem pedig elméleti igénnyel megírt mûvek. Emellett azonban

\footnotetext{
${ }^{35}$ Uo. 222-223.

${ }^{36}$ Uo. 223-224.
} 
nagyarányú hasonlóságok találhatók az európai és a magyar ideológiák tartalmi elemei között. Ami eltérés mutatkozik, az vagy a speciális magyar õstörténetnek köszönhetõ (Képes Krónika, Anonymus), vagy egyszerûen annak, hogy az elmélet Magyarországon nem tisztán, hanem más, egyébként nyugaton is meglévõ ideológiákkal összekeveredve került kifejezésre (Temesvári Pelbárt).

\section{FELHASZNÁLT IRODALOM}

Anonymus 1999. A magyarok cselekedetei.

In: Anonymus: A magyarok cselekedetei - Kézai Simon: A magyarok cselekedetei. 7-86. Budapest: Osiris.

Aquinó Szent Tamás: A háborúról. 2014.

In Aquinói Szent Tamás: A teológia foglalata II./II. 40. kérdés. 264-269. Budapest:

Gede Testvérek Bt.

Canning, Joseph 2002. A középkori politikai gondolkodás története 300-1450. Budapest: Osiris.

Barry, Brian 1967. Political Argument. London-New York: Routledge\&Kegan Paul-The Humanities Press.

Balogh József 1927. Szent István és a „Róma-eszme”. Budapesti Szemle 599 (1927): 89-95.

Dallos Edina 2000. Adalékok a fehérló monda értelmezéséhez. Ethnográfia 111 (1-2): 127-146.

Engel Pál 2003. A honfoglalás és a fehérló-monda „igaz története”.

In Engel Pál: Honor, vár, ispánság. 649-660. Budapest: Osiris Kiadó.

Erdõ Péter 2017. Hadviselés és háború a Katolikus Egyház tanításaiban. Magyar Sion új folyam XI (2): 269-281.

Györffy György 1993. Krónikáink és a magyar õstörténet - Régi kérdések-új válaszok. Budapest: Balassi Kiadó.

Isidore of Seville 2006. The Etymologies. Cambridge: CUP.

Isidore of Seville 2018. Sententiae, transl. Thomas L. Knoebel. New York/ Mahwah: NJ, The Newman Press.

Képes Krónika. 1986. Ford. Bellus Ibolya. Budapest: Európa Könyvkiadó.

Képes Krónika. 2004. Ford. Bollók János. Budapest: Osiris.

Russell, Frederick H. 1975. The Just War in the Middle Ages. Cambridge: CUP.

Szent István király kis legendája. 1983.

In Árpád-kori legendák és intelmek, vál. és szerk. Érszegi Géza, 16-22. Budapest: Szépirodalmi Könyvkiadó.

Szent István király nagy legendája.1983.

In Árpád-kori legendák és intelmek, vál. és szerk. Érszegi Géza,23-33. Budapest: Szépirodalmi Könyvkiadó.

Szent István király legendája Hartvik püspöktõl. 1983.

In Árpád-kori legendák és intelmek, vál. és szerk. Érszegi Géza, 34-53. Budapest: Szépirodalmi Könyvkiadó.

Szent István: Intelmek. 2014.

In Szent István király Intelmei és Törvényei. 13-33. Budapest: Szent István Társulat.

Szent László király legendája. 1983.

In Árpád-kori legendák és intelmek, vál. és szerk. Érszegi Géza, 95-102. Budapest:

Szépirodalmi Könyvkiadó.

Szûcs Jenõ 1988. Szent István Intelmei: Az elsõ magyarországi államelméleti mû.

In Szent István és kora, szerk. Glatz Ferenc, Kardos József, 32-53. Budapest:

MTA Történettudományi Intézet.

Temesvári Pelbárt 1982. György vitéz.

In Temesvári Pelbárt válogatott irásai. 218-225. Budapest: Európa Könyvkiadó/ Helikon Kiadó.

Temesvári Pelbár 2008. Szent László királyért: Harmadik beszéd az igazságos ítélkezésrõl az uralkodásban. In Középkori prédikációk Szent László királyról, szerk. Madas Edit, 225-237. Budapest: Romanika Kiadó. 
Tessore, Dag 2003. A háború misztikája. Budapest: Akadémiai Kiadó.

Tringli István 2017. Erõszak, hatalmaskodás, háború.

In Magyarország hadtörténete, fõszerk. Hermann Róbert, szerk. Veszprémy László, I. kötet, 12-16. Budapest: Zrínyi Kiadó.

Ujházi Lóránd, Horváth Tibor 2020. The Cult of Saint László (Saint Ladislaus) in the Hungarian Army. Hadtudományi Szemle 13 (1): 193-210.

Veszprémy László, szerk. 1999. Az elsõ és a második keresztes hadjárat korának forrásai. Budapest: Szent István Társulat.

Veszprémy László 2019. Történetirás és történetírók az Árpád-kori Magyarországon (XI-XIII. század közepe). Budapest: Line Design.

Wallace-Hadrill, J. M. 1975. "War and Peace in the earlier Middle Ages: The Prothero Lecture." Transactions of the Royal Historical Society 25. 157-174. 